\title{
MENINGKATKAN MOTIVASI BELAJAR SENI BUDAYA DENGAN LKPD DIGITAL
}

\author{
SRI WIDATI \\ SMPN 1 Wiradesa \\ Email : sriwidati@gmail.com
}

\begin{abstract}
ABSTRAK
Pandemi yang sudah berlangsung lama mempengaruhi proses pembelajaran secara umum. Peraturan dan keputusan pemerintah untuk melaksanakan pembelajaran jarak jauh ( PJJ) menjadi salah satu tujuan meminimalisasi penyebaran virus Covid-19. Permasalahan demi permasalahn mulai muncul terkait dengan proses pembelajaran. Kondisi ini menuntut guru lebih inovatif dan kreatif memilih strategi pembelajaran yang bermakna dan menyenangkan. LKPD digital menjadi alternatif pembelajaran jarak jauh di masa pandemi Covid-19. Penelitian ini bertujuan untuk mengetahui peningkatan motivasi belajar siswa, respon serta efektivitas penggunaan LKPD digital pada mata pelajaran seni budaya. Metode penelitian dilakukan dengan pendekatan kuantitatif dengan perumusan masalah, pengumpulan data, kesimpulan dan analisa hasil. Hasil penelitian menunjukakan adanya respon yang sangat tinggi pada penggunaan LKPD digital yaitu 80,6\% dan motivasi belajar siswa meningkat berdasarkan hasil observasi dan survei yang dilakukan peneliti. LKPD digital dapat menjadi stimulus-stimulus yang merangsang rasa ketertarikan atau keingintahuan siswa sehingga dalam proses pembelajaran siswa menjadi lebih semangat dan termotivasi.
\end{abstract}

Kata Kunci: Motivasi Belajar, Seni Budaya, LKPD digital

\section{PENDAHULUAN}

Sistem pendidikan di Indonesia menyatakan bahwa pembelajaran yang ideal yaitu pembelajaran yang mengutamakan pembudayaan dan pemberdayaan peserta didik sebagai pembelajar sepanjang hayat; pembelajaran yang menerapkan nilai-nilai dengan memberi keteladanan (ing ngarso sung tulodo), membangun kemauan (ing madyo mangun karso), dan mengembangkan kreativitas peserta didik dalam proses pembelajaran (tut wuri handayani). Pembelajaran dapat berlangsung di rumah, di sekolah, dan di masyarakat.

Pembelajaran seni budaya dapat menjadi salah satu sarana pencapaian tujuan pendidikan. Peran Pendidikan seni yang bersifat multidimensional yaitu mengembangkan kemampuan dasar fisik, perseptual,intelektual,emosional,sosial, kreativitas dan estetik (V.Lowenvield dalam Kamaril, 2001: 2). Multilingual yaitu mengembangkan kemampuan manusia dalam berkomunikasi secara visual atau rupa , bungi, gerak dan keterpaduannya (Goldberg, 1997: 8) dan multikultur yaitu memperluas pandangan tentang kebudayaan dengan memasukkan lingkungan alam dan lingkungan sosial budaya , sebagai sumber daya lingkungan yng digunakan dan dimanfaatkan untuk pembentukan kepribadian manusia secara utuh, bukan hanya mengembangkan kemampuan estetika saja tetapi dapat mengembangkan kemampuan logika dan etika.

Pembelajaran seni dapat menjadi proses pendidikan olah rasa membentuk pribadi harmonis dan menumbuhkan multikecerdasan. Pembelajaran seni di sekolah memberi bekal ketrampilan yang spesifik kepada siswa, mengembangkan potensi yang dimiliki siswa mencakup kepekaan estetik yang berkaitan dengan pengetahuan artistik, sensitivitas terhadap lingkungan (alam, sosial dan budaya), rasa kemanusiaan (toleransi, apresiatif), konsep perseptual dan kemampuan dalam penilaian estetik (Pekerti,2008: 27).

Masa pandemi yang terjadi di Indonesia tentu saja mempengaruhi proses pembelajaran seni budaya, karena diberlakukannya PJJ. Pembelajaran Jarak Jauh (PJJ) mempunyai banyak kendala dari segi keterbatasan waktu, sulitnya komunikasi, kesulitan memahami materi, diperlukan motivasi, dan munculnya kejenuhan. Kondisi seperti itu menuntut guru berperan aktif dalam menentukan pendekatan, dan strategi pembelajaran yang tepat. Minat belajar siswa 
akan tumbuh apabila guru lebih kreatif dalam mengajar (Uno, Hamzah B \& Nurdin,M., 2015: 169). Berlangsungnya PJJ atau BDR tentu saja berhubungan erat dengan kemampuan guru serta peserta didik dalam memanfaatkan informasi teknologi sebagai media dalam proses pembelajaran.

Praktik PJJ dengan belajar dari rumah belum mencapai tujuan yang diharapkan karena sebagian besar kegiatan pembelajaran hanya bersifat satu arah. Layanan pembelajaran yang bersifat dua arah saling timbal balik masih terbatas jumlahnya. Tentu saja hal ini dipengaruhu banyak faktor diantaranya: kemampuan guru menguasai teknologi belu optimal, demikian juga siswa. Sarana prasarana yang terbatas pada wilayah tertentu terkait jaringan internet, sinyal, komputer, maupun gawai. Keluhan guru muncul ketika siswa tidak disiplin mengumpulkan tugas bahkan ada yang tidak mengerjakan tugas. Tentu saja ini hal yang sangat tidak diharapkan guru. Guru sering menunggu respon lengkap dalam waktu lama. Kemungkinan hal yang dirasakan siswa pada pelajaran diantaranya pemberian tugas banyak setiap pertemuan, tidak ada variasi atau monoton, sehingga kurang menarik minat dan membosankan. Jika hal ini dibiarkan maka tujuan pembelajaran tidak akan optimal.

Penulis berusaha menerapkan satu cara untuk meminimalisasi kejenuhan siswa yaitu dengan menggunakan Lembar Kerja Peserta Didik digital. Menurut Prastowo,Andi (2011: 204) LKPD didefinisikan sebagai bahan ajar cetak berupa lembar-lembar kertas yang berisi materi, ringkasan, dan petunjuk-petunjuk pelaksanaan tugas yang harus dikerjakan oleh peserta didik, mengacu pada kompetensi dasar yang dicapai. Penulis menggunakan jenis LKPD digital dengan alasan pembelajaran masih dilakukan secara daring, sehingga muncul hipotesa bahwa penggunaan LKPD digital ini dapat meningkatkan motivasi belajar siswa di masa pandemi. Perkembangan tehnologi digital merupakan hasil rekayasa akal, pikiran dan kecerdasan manusia, yang tercermin dalam kemajuan ilmu pengetahuan, selanjutnya memberikan manfaat dalam segala aspek kehidupan manusia (Muhasim, 2017: 1). LKPD digital dengan memanfaatkan teknologi komputer dapat menjadi alternatif pilihan PJJ di masa pandemi seperti sekarang ini. Menurut Hamalik ( 2016: 236 ) bahwa media pembelajaran dalam hal ini teknologi komputer dapat melayani siswa sebagai alat bantu pembelajaran.

\section{METODE PENELITIAN}

Penelitian ini menggunakan metode penelitian kuantitatif dengan alat pengumpulan data berupa angket dan observasi didukung dokumen serta studi kepustakaan yang terkait dengan penelitian. Proses diawali dengan penentuan fokus masalah, hipotesa, menentukan métode penelitian, pengumpulan data, menarik kesimpulan dan analisa hasil untuk membuktikan hipotesa, hal ini merujuk métode penelitian kuantitatif yang dikemukakan Syahrum \& Salim (2012: 76-77).

Pengolahan data dari respon penggunaan LKPD digital yang terkumpul dari tiap kelas, akan disajikan berbentuk prosesentase yang dihitung berdasarkan rumus deskriptif prosentase sebagai berikut:

Respon Siswa Terkumpul X 100\% = Prosentase Respon Kelas

Respon Siswa ideal

Data kuantitas berbentuk angka dikonversi untuk mendapatkan kriteria kualitatif dari data pengumpulan respon siswa. Pedoman konversi yang dipakai terbagi dalam 4 kelas Sangat Tinggi,Tinggi,Sedang,Rendah.Selengkapnya tergambar dalam tabel 1.

Tabel 1.Pedoman Konversi Kriteria Prosentase Pengumpulan Respon Siswa

$\begin{array}{ccc}\text { No } & \text { Interval \% } & \text { Kriteria } \\ 1 & 76-100 & \text { Sangat Tinggi } \\ 2 & 51-75 & \text { Tinggi } \\ 3 & 26-50 & \text { Sedang } \\ 4 & 0-25 & \text { Rendah }\end{array}$




\section{HASIL DAN PEMBAHASAN}

\section{Hasil}

Penelitian ini dilakukan di SMP Negeri 1 Wiradesa Pekalongan. Adapun subyek penelitian kelas 9 sebanyak 8 kelas yaitu 9.1, 9.2, 9.3, 9.4, 9.5, 9.6, 9.7 dan 9.8. Jumlah siswa kelas 9 keseluruhan 254 siswa. Penelitian dilaksanakan pada semester 1 tahun pelajaran $2021 / 2022$.

Hasil dari penelitian ini yaitu, pertama berupa prosentase pengumpulan respon LKPD semua siswa kelas 9, kedua yaitu análisis indikator peningkatan motivasi belajar siswa, serta karakteristik LKPD digital menggunakan aplikasi Liveworksheet. berikut:

Hasil prosentase pengumpulan respon pekerjaan LKPD siswa diperoleh data sebagai

Tabel 2. Prosentase Pengumpulan Respon Siswa Secara Klasikal

\begin{tabular}{lllll}
\hline No & Kelas & $\begin{array}{l}\text { Jumlah } \\
\text { respon }\end{array}$ & $\begin{array}{l}\text { Total } \\
\text { Siswa }\end{array}$ & Prosentase \\
\hline 1 & 9.1 & 31 & 32 & $96,8 \%$ \\
2 & 9.2 & 29 & 32 & $90,6 \%$ \\
3 & 9.3 & 27 & 32 & $84,3 \%$ \\
4 & 9.4 & 25 & 32 & $78,1 \%$ \\
5 & 9.5 & 24 & 32 & $75 \%$ \\
6 & 9.6 & 24 & 32 & $75 \%$ \\
7 & 9.7 & 24 & 32 & $75 \%$ \\
8 & 9.8 & 21 & 30 & $70 \%$ \\
\multicolumn{2}{l}{ RERATA } & 31,7 & 254 & $80,6 \%$ \\
\hline
\end{tabular}

Prosentase pengumpulan respon dari kelas yang diteliti terendah $70 \%$ sedangkan prosentase pengumpulan respon tertinggi $.96,8 \%$. Jika disajikan dalam grafik dapat dilihat dalam grafik 1.1. berikut ini.

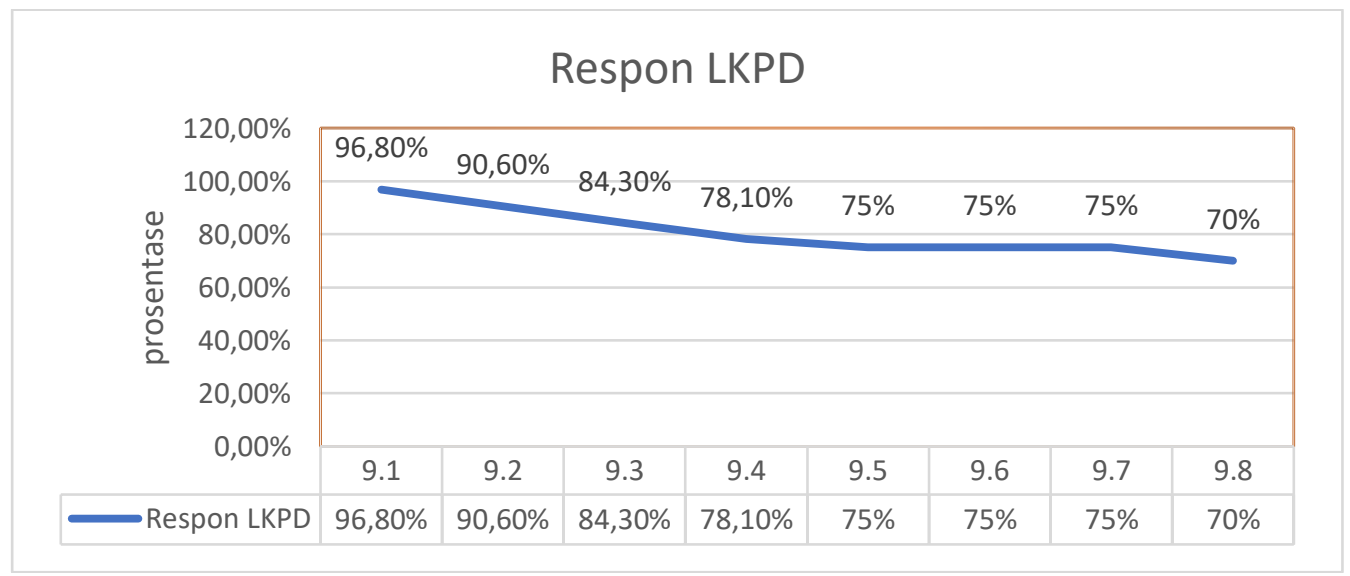

Gambar 1. Grafik Pengumpulan Respon Siswa

Hasil kedua yaitu motivasi belajar siswa meningkat. Motivasi pada dasarnya dapat membantu dalam memahami dan menjelaskan perilaku individu, termasuk perilaku individu yang sedang belajar. Indikator peningkatan motivasi siswa menurut Novianti, N. R. (2011:158166 ) bahwa untuk mengetahui tingkat motivasi belajar pada siswa terdapat beberapa indikator motivasi belajar siswa meliputi: a. Ketekunan dalam belajar, b. Minat dan ketajaman perhatian dalam belajar, c. Ulet dalam menghadapi kesulitan, d. Mandiri dalam belajar, e. Keinginan berhasil dalam belajar, f. Reward/pujian/penghargaan

Merujuk pada pendapat tersebut maka indikator dan diskriptor motivasi belajar dalam penelitian ini dapat di lihat pada tabel 3. 
Tabel 3. Uraian Indikator Motivasi Belajar dan Deskriptornya

\begin{tabular}{|c|c|c|}
\hline No & Indikator & Deskriptor \\
\hline 1 & $\begin{array}{l}\text { Siswa mempunyai keinginan untuk } \\
\text { berhasil }\end{array}$ & $\begin{array}{l}\text { Belajar dengan sungguh-sungguh } \\
\text { Mengerjakan tugas-tugas dari guru }\end{array}$ \\
\hline 2 & $\begin{array}{l}\text { Siswa memiliki dorongan tinggi } \\
\text { untuk belajar }\end{array}$ & $\begin{array}{l}\text { Memperhatikan saat proses pembelajaran } \\
\text { Mengikuti proses pembelajaran dengan } \\
\text { tanggungjawab }\end{array}$ \\
\hline 3 & $\begin{array}{l}\text { Siswa mempunyai cita-cita dan } \\
\text { harapan }\end{array}$ & $\begin{array}{l}\text { Berusaha memperoleh nilai yang tinggi } \\
\text { Tidak mudah putus asa }\end{array}$ \\
\hline 4 & $\begin{array}{l}\text { Siswa senang penghargaan dalam } \\
\text { belajar }\end{array}$ & $\begin{array}{l}\text { Senang berkompetensi untuk mendapat nilai } \\
\text { terbaik } \\
\text { Merespon teman lain yang berprestasi }\end{array}$ \\
\hline 5 & $\begin{array}{l}\text { Siswa senang dengan kegiatan yang } \\
\text { menarik dalam belajar }\end{array}$ & $\begin{array}{l}\text { Mengerjakan tugas-tugas yang menantang } \\
\text { Mau mencari cara lain untuk menyelesaikan } \\
\text { tugas-tugas pembelajaran }\end{array}$ \\
\hline & $\begin{array}{l}\text { Siswa mempunyai lingkungan } \\
\text { belajar kondusif }\end{array}$ & $\begin{array}{l}\text { Saling membantu jika mengalami kesulitan } \\
\text { belajar } \\
\text { Berkompetisi sportif dalam pembelajaran }\end{array}$ \\
\hline
\end{tabular}

Hasil ketiga yaitu tentang karakteristik LKPD digital. LKPD digital tersebut dibuat dengan Liveworksheet oleh guru setelah mendownload aplikasi. LKPD yang terdiri dari komponen identitas peserta didik, kompetensi dasar dan tujuan pembelajaran, materi seni patung, video terkait dengan materi seni patung dan lembar kerja berupa uji kompetensi.

\section{Pembahasan}

Pembahasan diawali dengan proses penyusunan LKPD digital. Penulis berasumsi bahwa penggunaan LKPD digital dapat efektif dan bermakna dalam pembelajaran pada masa pandemi dengan PJJ daring. Menurut Trianto ( 2009:29), belajar akan lebih bermakna jika anak mengalami langsung apa yang dipelajarinya dengan mengaktifkan lebih banyak indera daripada hanya mendengarkan orang/guru menjelaskan. Oleh karena itu maka penulis memilih LKPD digital sebagai alternatif media pembelajaran selama PJJ daring.

Guru dalam hal ini sebagai penulis merencanakan materi LKPD digital dengan komponen identitas siswa dan sekolah, kompetensi dasar dan tujuan pembelajaran, materi pembelajaran berupa teks dan video untuk pengamatan siswa dan terakhir lembar kerja atau uji kompetensi. Bentuk uji kompetensi berupa jawab singkat, drag drop, pilihan ganda dan menjodohkan. Menurut Kustandi,C \& Sutjipto,B (2011:115) bahwa pengembangan dan penggunaan media perlu dilakukan secara sistematis berdasarkan langkah-langkah yang saling terkait, untuk menghasilkan pembelajaran yang bermanfaat. Demikian juga pada LKPD digital secara sistematis sudah lengkap mulai dari $\mathrm{KD}$, tujuan pembelajaran, langkah pembelajaran, materi, sampai dengan berbagai variasi bentuk penilaian yang menarik tanpa mengurangi esensi tujuan utama pembelajaran. Adapun langkah-langkah penulisan LKPD yang dapat dikembangkan oleh guru secara mandiri dalam pembelajaran disampaikan dalam seminar tentang pengembangan LKPD oleh Katriani (2014: 4) yaitu: 1. melakukan analisis kurikulum; $\mathrm{KI}$, KD, indikator dan materi pembelajaran. 2. Menyusun peta kebutuhan LKPD. 3. Menentukan judul LKPD. 4. Menulis LKPD. 5. Menentukan alat penilaian.

Langkah awal yaitu guru menyusun LKPD dalam bentuk Pdf agar dapat diaplikasikan ke liveworksheet. Langkah berikutnya setelah proses pembuatan LKPD selesai maka akan diperoleh link LKPD yang nantinya dikirimkan pada peserta didik disertai langkah-langkah mengerjakan LKPD ke grup Whatshap. Guru juga melampirkan alamat email sesuai yang 
didaftarkan di liveworksheet agar siswa dapat mengirimkan hasil jawabannya. Siswa akan langsung dapat melihat hasil LKPD yang telah dikerjakan sehingga mereka dapat melakukan perbaikan jika hasil belum optimal. Penyusunan LKPD digital tentu saja membutuhkan kemampuan guru untuk menguasai teknologi. LKPD digital merupakan salah satu media by design. Menurut Kustandi, C \& Sutjipto,B (2011: 115) bahwa media by design adalah media yang dirancang khusus sesuai dengan kebutuhan pembelajaran guru untuk mencapai tujuan. Penggunaan media pengajaran sangat bergantung pada tujuan pengajaran, bahan pengajaran, kemudahan memperoleh media yang dieprlukan serta kemampuan guru dalam menggunakannya (Sudjana, Nana \& Rivai, Ahmad, 2013: 4). Dengan demikian peran guru dalam menentukan jenis media sangat penting karena mereka yang lebih memahami materi dan tujuan pembelajaran.

Beberapa hal yang menjadi alasan penggunaan LKPD digital, selain mengatasi kebosanan siswa selama PJJ yaitu lebih memudahkan dalam menyampaikan materi dan penilaian selama PJJ. Menurut Wena (2009: 208) pembelajaran berbasis komputer memudahkan siswa memahami konsep-konsep yang bersiafat abstrak yang akhirnya meningkatkan ahsil pembelajaran, maka pengembangan pembelajaran berbasis komputer sangat penting bagi guru, siswa dan sekolah. Media adalah komponen sumber belajar atau wahana fisik yang mengandung materi instruksional di lingkungan siswa yang dapat merangsang siswa untuk belajar (Azhar Arsyad, 2011: 4). Demikian juga dengan penggunaan LKPD digital mampu meningkatkan motivasi siswa untuk belajar.

Hasil respon pengumpulan LKPD digital menunjukkan bahwa peserta didik memiliki respon yang sangat tinggi terhadap pembelajaran seni patung dengan indikasi LKPD digital cepat terkumpul dengan batas waktu yang telah ditentukan. Meskipun ada beberapa siswa yang terlambat karena kendala jaringan internet. Berdasarkan data dan pedoman konversi kriteria prosentase pengumpulan respon siswa maka termasuk respon sangat tinggi dengan prosentase $80,6 \%$.

Berdasarkan fungsi motivasi yang dikemukakan oleh Sardiman A.M (2011: 85) bahwa motivasi mempunyai fungsi pada diri seseorang, dengan adanya motivasi maka seseorang dapat mengalami perubahan ke arah yang lebih baik. Disebutkan juga ada tiga fungsi motivasi dalam belajar yaitu : 1) Mendorong manusia untuk berbuat, yaitu motivasi sebagai motor penggerak dari setiap kegiatan yang dikerjakan. 2) Menentukan arah perbuatan, yakni ke arah tujuan yang hendak dicapai. Dengan demikian motivasi dapat memberikan arah dari kegiatan yang harus dikerjakan sesuai dengan rumusan tujuannya. 3) Menyeleksi perbuatan, yaitu motivasi menentukan perbuatan yaitu motivasi menentukan perbuatan-perbuatan apa yang harus dikerjakan guna mencapai tujuan dan menyingkirkan perbuatan yang tidak bermanfaat. Begitu halnya motivasi belajar siswa untuk mengikuti pembelajaran seni budaya materi seni patung di SMPN 1 Wiradesa, terbukti ada peningkatan ditandai dengan kesungguhan mereka mengerjakan LKPD digital dengan tepat waktu, kedua motivasi untuk berkomunikasi ketika mengalami kesulitan atau kendala dalam menggunakan LKPD digital melalui WhatsApp grup. Ketiga, siswa lebih termotivasi untuk mengerjakan lembar kerja dengan sebaik-baiknya karena mereka harus mengisi list nilai di WhatsApp grup, setelah selesai mengerjakan karena nilai dapat dilihat langsung. Tentu saja hal ini memotivasi mereka untuk berkompetisi memperoleh nilai yang terbaik sebagai indikator siswa memiliki motivasi tinggi dengan mempunyai keinginan untuk berhasil dan berada pada lingkungan yang kondusif.

Terkait dengan penggunaan LKPD digital maka guru melakukan survei dengan memberikan angket melalui google form kepada siswa yang berisi kelebihan dan kekurangan dalam pembelajaran menggunakan LKPD digital. Hasil survei yang diperoleh sebagai berikut: 1) siswa senang dengan LKPD digital karena mudah memahami materi teks maupun materi berupa audio visual dalam satu link, 2) LKPD digital dapat dibuka dengan komputer, laptop maupun android tanpa mendownload aplikasi. Meskipun memiliki kelebihan tentu saja suatu aplikasi memiliki kekurangan. Kekurangan atau kendala yang dialami siswa yaitu jaringan 
internet yang terkadang susah sinyal karena harus menggunakan internet ketika mengerjakan LKPD.

\section{KESIMPULAN}

Berdasarkan latar belakang dan hasil penelitian maka penulis dapat menyimpulkan bahwa guru harus lebih inovatif dan mampu memberikan solusi strategi pembelajaran yang tidak membosankan pada pembelajaran jarak jauh di masa pandemi Covid-19. Guru perlu belajar teknologi informasi terkait pemanfaatan TI untuk membuat berbagain media pembelajaran yang efektif dan menyenangkan. Penggunaan LKPD digital menjadi salah satu alternatif media pembelajaran yang menarik serta dapat meningkatkan motivasi belajar siswa pada pembelajaran jarak jauh (PJJ) di masa pandemi.

\section{DAFTAR PUSTAKA}

Arsyad, Azhar. (2015). Media Pembelajaran. Jakarta: Raja Grafindo Persada.

Goeldberg, Merryl. (1997). Art and Learning An Integrated Approachto Teaching and Leraning in Multicultural and Multilingual Setting. New York: Longman.

Hamalik, Oemar. (2016). Proses Belajar Mengajar. Jakarta: Bumi Aksara.

Kamaril,Cut. (2001). Konsep Pendidikan Seni Tingkat SD-SLTP-SMU. Makalah Seminar dan Lokakarya Nasional Pendidikan Seni . 10-20 April 2001. Jakarta: Hotel Indonesia.

Katriani, Laila.( 2014 ). Pengembangan Lembar Kerja Peserta Didik ( (LKPD). Makalah PPM "Pelatihan Pembuatan Perencanaan Pembelajaran IPA untuk Kegiatan Belajar Mengajar (KBM) di Kelas Sebagai Implementasi Kurikulum 2013 bagi Guru SMP Se-Kecamatan Danurejan, Kota Yogyakarta” Tanggal 24 Oktober 2014.

Kustandi,C \& Sutjipto, B. (2011). Media Pembelajaran Manual dan Digital. Bogor: Ghalia Indonesia.

Muhasim. (2017). Pengaruh Tehnologi Digital terhadap Motivasi Belajar Peserta Didik. Jurnal PALAPA, 5(2)

Novianti, N. R. (2011). Kontribusi pengelolaan laboratorium dan motivasi belajar siswa terhadap efektivitas proses pembelajaran. Jurnal Pendidikan MIPA

Pekerti, Widia. Dkk. (2008). Media Pengembangan Seni. Jakarta: Universitas Terbuka.

Prastowo, Andi. (2011). Panduan Kreatif Membuat Bahan Ajar Inovatif: Menciptakan Metode Pembelajaran yang Menarik dan Menyenangkan. Yogyakarta: Diva Press.

Sardiman. (2011). Interaksi dan Motivasi Belajar Mengajar. Yogyakarta: Raja Grafindo Persada.

Sudjana, Nana \& Rivai, Ahmad. (2013). Teknologi Pengajaran. Bandung: Sinar Baru Algen. Syahrum \& Salim. (2012). Metodologi Penelitian Kuantitatif. Bandung: Citapustaka Media. Trianto. (2009). Mengembangkan Model Pembelajaran Tematik. Jakarta: Prestasi Pustaka.

Uno, Hamzah B. (2013). Teori Motivasi dan Pengukurannya Analisis di Bidang Pendidikan. Jakarta: Bumi Aksara.

Uno, Hamzah B \& Nurdin,M. (2015). Belajar dengan Pendekatan Pailkem. Jakarta: Remaja Rosdakarya.

Wena, Made. (2009). Strategi Pembelajaran Kreatif Kontemporer. Jakarta: Bumi Aksara. 